\title{
HUBUNGAN ANTARA COPING STRES DENGAN KECEMASAN PADA ORANG-ORANG PENGIDAP HIV/AIDS YANG MENJALANI TES DARAH DAN VCT (VOLUNTARY COUNSELING TESTING)
}

\author{
Erna Agustina Yudiati dan Esthi Rahayu
}

\begin{abstract}
Permasalahan AIDS (Acquired Immuno Deficiency Virus) berkembang dengan cepat dan menjadi sebuah ancaman kesehatan dunia yang utama. Salah satu layanan terhadap pemberian informasi seputar HIV/AIDS adalah melalui VCT (Voluntary Counseling Testing). Adanya diskriminasi terhadap HIV/AIDS ini membuat keikutsertaan seseorang mengikuti VCT (Voluntary Counseling Testing) atau tes konseling sukarela bagi seseorang yang ingin mengetahui status HIV nya mungkin rendah akibat takut mendapat diskriminasi. Bagi seseorang yang akan menjalankan tes, muncul berbagai reaksi emosi seperti cemas dan takut, terutama ketika mengetahui hasil yang diperoleh positif.. Kemampuan seorang individu untuk dapat menyesuaikan diri dengan stressor yang dialaminya itulah yang disebut dengan coping stress. Hipotesis penelitian adalah ada hubungan yang negatif antara coping stres dengan kecemasan. Artinya semakin baik coping stres maka semakin rendah kecemasan dan sebaliknya. Teknik analisa data yang dipakai dalam penelitian ini adalah analisa kuantitatif non parametrik: Spearman's rho. Hasilnya adalah ada hubungan yang negatif antara coping stres dengan kecemasan.
\end{abstract}

\section{1) Staf pengajar Fakultas Psikologi UNIKA Seogijapranata, Semarang}

LATAR BELAKANG

MASALAH

VCT (Voluntary

Counseling Testing) adalah salah

satu layanan terhadap pemberian

\author{
informasi seputar HIV/AIDS. \\ VCT (Voluntary Counseling \\ Testing) yaitu proses yang \\ melibatkan individu dalam \\ menjalani konseling rahasia untuk
}


mengetahui status HIV seseorang dengan prinsip bahwa VCT dilakukan secara sukarela. Konseling VCT ini terdiri dari pre-test dan pos test counseling. Selama pre test counseling, para individu/pasangan mendapat informasi yang akurat dan lengkap tentang HIV/AIDS. Setelah konseling, individu tersebut dapat memutuskan apakah memilih untuk melakukan tes HIV atau tidak (National AIDS Control Organization, 2004).

Menurut Finger (2002) yang melakukan penelitian terhadap para kaum muda, sebelum tes HIV dilakukan, penting bagi para konselor menyiapkan tingkat kematangan para kaum muda tersebut terhadap kemampuan mengatasi hasil tes HIV. Penting untuk tidak menyalahkan, menciptakan hubungan baik dan membangkitkan para kaum muda terutama pada saat hasilnya positif. Tidak mudah bagi seseorang untuk memutuskan melakukan tes darah, adanya ketidaksiapan dan penolakan terhadap hasil tes darah yang akan diperoleh, terutama jika hasilnya positif.

$$
\text { Adanya diskriminasi }
$$
terhadap HIV/AIDS membuat keikutsertaan seseorang mengikuti VCT (Voluntary Counseling Testing) atau tes konseling sukarela bagi seseorang yang ingin mengetahui status HIV nya mungkin rendah akibat takut mendapat diskriminasi. Ketakutan akan diskriminasi juga dapat menurunkan jumlah orang-orang yang akan kembali untuk mengambil hasil tesnya. Finger (2002) mengatakan beberapa studi para kaum muda mengalami ketakutan melakukan tes.

$$
\text { Konseling HIV ini }
$$
merupakan sebuah tantangan. Beberapa orang yang akan melakukan tes mengalami kecemasan apabila hasil yang didapat positif. Lainnya berpendapat bahwa hasil tes tidak akan dirahasiakan, sehingga 
merasa akan kehilangan pasangan dan pelayanan yang akan dikenai biaya atau disediakan tempat yang tidak nyaman (menyenangkan). Banyak orang mengatakan takut untuk mencari pelayanan HIV karena rasa takut terhadap stigma dan diskriminasi dari sanak famili dan masyarakat (Finger, 2002).

Kemampuan seorang individu untuk dapat menyesuaikan diri dengan stressor yang dialaminya itulah yang disebut dengan coping stress. Reaksi manusia terhadap stres bersifat menyerang, menarik diri atau kesepakatan berdamai. Masing-masing reaksi itu dapat terjadi secara terbuka atau tersamar. Individu dapat menurunkan taraf aspirasinya (hasrat atau cita-cita) saat menghadapi kegagalan, atau meningkatkan upayanya untuk mencapai tujuan. Segala reaksi tersebut adalah upaya untuk mengimbangi problem sedemikian rupa sehingga dapat mencapai atau mempertahankan suatu keseimbangan psikobiososial untuk memenuhi kebutuhan-kebutuhan dasarnya.

Oleh karena itu, peneliti ingin mengetahui apakah ada hubungan antara coping stres dengan kecemasan pada orangorang beresiko mengidap HIV/AIDS yang menjalani tes darah dan VCT (Voluntary Counseling Testing)"

\section{VOLUNTARY COUNSELING}

\section{TESTING}

\section{Menurut NationaL AIDS}

Control Organization (2004), konseling HIV adalah percakapan rahasia antara seseorang dengan konselor yang bertujuan memungkinkan seseorang mengatasi stres dan membuat keputusan pribadi yang berhubungan dengan HIV/AIDS termasuk informasi, pendidikan, dukungan psikologis yang memudahkan seseorang mengatasi dan mencegah perilaku Konseling VCT terdiri dari pre-test dan post-tes counseling. Pre-test counseling 
menghadirkan konselor dengan ketepatan informasi, menilai resiko dan menanggapi kebutuhan-kebutuhan klien. Banyak orang merasa takut mencari tes HIV karena takut akan stigma dan diskriminasi dari sanak keluarga dan masyarakat. Pelayanan VCT seharusnya selalu melindungi kerahasiaan kebutuhan individu (National AIDS Control Organization, 2004).

\section{KECEMASAN dan COPING} STRES

Menurut Kaplan, Saddock dan Grebb (Fausiah dan Widuri, 2005) kecemasan adalah respons terhadap situasi tertentu yang mengancam dan merupakan hal yang normal terjadi menyertai perkembangan, perubahan, pengalaman baru atau yang belum pernah dilakukan serta dalam menemukan identitas diri dan arti hidup. Pada kadar yang rendah, kecemasan membantu individu untuk bersiaga mengambil langkah-langkah mencegah bahaya atau untuk memperkecil dampak bahaya tersebut. Kecemasan sampai pada taraf tertentu dapat mendorong meningkatnya performa. Kecemasan semacam ini disebut facilitating anxiety, namun apabila kecemasan sangat besar, justru akan sangat mengganggu yang disebut debilitating anxiety. Takeichi, dkk (2001), ketika seseorang mengalami stress psikologis eksternal, individu akan memberikan makna subyektif terhadap stress yang dialami dan kecemasanpun terjadi. Kecemasan terjadi ketika adanya ketidakpastian dan ketidakstabilan elemen kehidupan dalam masyarakat dewasa ini.

Carson (2000) mengungkapkan bahwa istilah stress biasanya mengacu pada dua hal, yaitu tuntutan penyesuaian yang ditempatkan pada diri organisme dan respon internal organisme secara biologis dan psikologis terhadap berbagai tuntutan. Tingkah laku seseorang 
dalam menghadapi masalah, tekanan dan tantangan disebut coping stres (Salomo dikutip Setyowati, 2006).mengelola jarak antara tuntutan-tuntutan dalam hidup, baik tuntutan yang berasal dari dalam atau pun dari luar diri individu dengan kemampuan atau sumber-sumber daya yang dimiliki untuk memenuhi tuntutan tersebut.

\section{HUBUNGAN ANTARA COPING STRES DENGAN KECEMASAN}

Coping stres adalah
tingkah laku seseorang dalam
menghadapi masalah, tekanan dan
tantangan (Salomo dikutip Setyowati, 2006). Oleh karena itu, coping stres merupakan respon dan strategi yang dilakukan individu terhadap stres untuk mentolerir dan mengurangi efek negative dari situasi yang dihadapi, dengan cara mengelola jarak antara tuntutan-tuntutan dalam hidup, baik tuntutan yang berasal dari dalam atau pun dari luar diri individu dengan kemampuan atau sumber-sumber daya yang dimiliki untuk memenuhi tuntutan tersebut.

Dalam merepon terhadap masalah, seseorang dapat melakukan dengan problem focused coping maupun emotion focused coping (Folkman, dkk, 1986). Cara seseorang dalam mengatasi masalah, dapat mempengaruhi kecemasan yang dialami olehnya. Meichati (1983) menyatakan bahwa ada empat sifat dasar yang dapat menyebabkan kecemasan, yaitu kebingungan terhadap apa yang dihadapi, ketidaktentuan mengenai suatu hal, ketidaktegasan, keadaan tidak mampu, tidak berdaya dan rasa dendam atau sentimen.

\section{HIPOTESIS}

Ada hubungan yang negatif antara coping stres dengan kecemasan. Artinya semakin baik coping stres maka semakin rendah kecemasan dan sebaliknya.

\section{IDENTIFIKASI VARIABEL}


Dalam penelitian ini menggunakan dua variabel utama, yaitu

Variabel tergantung : Kecemasan

Variabel bebas

Coping Stres

\section{SUBJEK PENELITIAN}

Populasi penelitian ini memiliki ciri-ciri sebagai berikut:

a. Para pelaku yang memiliki perilaku resiko tinggi

b. Melakukan konseling dan tes darah (HIV) secara sukarela (tanpa paksaan)

c. Pernah mendapat pengarahan tentang HIV/AIDS

d. Pendidikan minimal SLTP

Lokasi penelitian: di beberapa tempat di Semarang. Tehnik pengambilan sampe adalah insidental purposive sampling. Jumlah subyek yang terlibat di dalam penelitian ini ada 11 orang.

\section{METODE PENGUMPULAN}

\section{DATA}

Dalam penelitian ini menggunakan dua macam skala, yaitu:

a. Skala kecemasan
Skala kecemasan disusun oleh peneliti dengan berdasar pada gejala-gejala kecemasan, yaitu: gejala fisik dan gejala psikis. Jumlah item ada 31 .

b. Skala coping stres.

Skala coping stres yang digunakan di dalam penelitian ini merupakan terjemahan dari The Ways Of Coping (set 1) milik Lazarus dan Folkman yang direvisi pada tahun 1985 (Folkman, dkk, 1986). Bentukbentuk coping:

1) Problem focused coping, meliputi: planful problem solving, confrontative coping

2) Emotion Focused coping, meliputi: distancing, self control, seeking social support, accepting responsibility, escape avoidance, positive reappraisal

\section{TEKNIK ANALISIS DATA}

Teknik analisa data yang dipakai dalam penelitian ini adalah analisa kuantitatif non parametrik: Spearman's rho. 


\section{HASIL PENELITIAN}

\section{Validitas dan Reliabilitas}

a. Jumlah item alat ukur Kecemeasan ada 31 item. Jumlah item yang valid ada 16 item, dimana rangenya antara 0,453-0,854. Meliputi:

12 item yang mengungkap kecemasan dari segi fisik dan 4 item yang mengungkap kecemasan dri segi psikis. Reliabilitas $=0,936$ (Alpha Cronbach).

b. Jumlah item alat ukur Coping ada 50 item. Jumlah item yang valid ada19 item, dimana rangenya antara 0,547-0,968. Meliputi: 2 item yang mengungkap distancing, 2 item yang mengungkap self control, 3 item yang mengungkap seeking social support, 1 item item yang mengungkap accepting responbility, 5 item yang mengungkap positive reappraisal, 4 item yang mengungkap planful problem solving, 2 item yang mengungkap confrontative coping. Untuk bentuk coping, escape avoidance (reaksi berkhayal dan usaha menghindar atau melarikan diri dari permasalahan) , semua itemnya gugur. Reliabilitas $=0,971$ (Alpha Cronbach).

\section{Uji Asumsi}

a. Uji normalitas Coping Stess: Kolmogorov Sminov $\mathrm{Z}=$ 0,839 dengan $\mathrm{p}>0,05$, dimana $\mathrm{p}=0,482$. Artinya: datanya berdistribusi normal.

b. Uji normalitas Emotion Focused Coping: Kolmogorov Sminov $Z=0,751$ dengan $\mathrm{p}>0,05$, dimana $\mathrm{p}=0,626$. Artinya: datanya berdistribusi normal.

c. Uji normalitas Problem Focused Coping: Kolmogorov Sminov $Z=0,419$ dengan $\mathrm{p}>0,05$, dimana $\mathrm{p}=0,995$. Artinya: datanya berdistribusi normal.

d. Uji normalitas Kecemasan: Kolmogorov Sminov $\mathrm{Z}=$ 
0,571 dengan $\mathrm{p}>0,05$, dimana $\mathrm{p}=0,900$. Artinya: datanya berdistribusi normal.

e. Uji linieritas Kecemasan dan Coping Stress: F linier = 15,358 dengan $\mathrm{p}<0,01$, dimana $\mathrm{p}=0,004$. Artinya: hubungan kedua variabel tersebut linier.

f. Uji linieritas Kecemasan dan Emotion Focused Coping : F linier $=17,682$ dengan $\mathrm{p}<0,01$, dimana $\mathrm{p}=0,002$. Artinya: hubungan kedua variabel tersebut linier.

g. Uji linieritas Kecemasan dan Problem Focused Coping : F linier $=8,754$ dengan $\mathrm{p}<0,01$, dimana $\mathrm{p}=0,016$. Artinya: hubungan kedua variabel tersebut linier.

\section{$\underline{\text { Uji Hipotesis }}$}

Berdasarkan uji analisa data yang sudah dilakukan dengan Spearman's rho

terhadap 11 subjek penelitian, didapatkan hasil sebagai berikut : a. Ada hubungan negatif antara coping stress dengan kecemasan. Koefisien korelasi $=-0,854$, dengan $\mathrm{p}<0,01$ dimana $\mathrm{p}=0,0$. Artinya: ada hubungan negatif yang sangat signifikan antara coping stress dengan kecemasan . Semakin mampu melakukan coping stres, maka kecemasan akan semakin menurun dan sebaliknya.

b. Ada hubungan negatif antara emotion focused coping dengan kecemasan. Koefisien korelasi $=-0,911$, dengan $\mathrm{p}<0,01$ dimana $\mathrm{p}=0,0$. Artinya: ada hubungan negatif yang sangat signifikan antara emotion focused coping dengan kecemasan. Semakin mampu melakukan emotion focused coping, maka kecemasan akan semakin menurun dan sebaliknya.

c. Ada hubungan negatif antara problem focused coping dengan kecemasan. Koefisien korelasi $=-0,748$, dengan 
$\mathrm{p}<0,01$ dimana $\mathrm{p}=0,0$.

Artinya: ada hubungan negatif yang sangat signifikan antara problem focused coping dengan kecemasan. Semakin mampu melakukan problem focused coping, maka kecemasan akan semakin menurun dan sebaliknya.

\section{PEMBAHASAN}

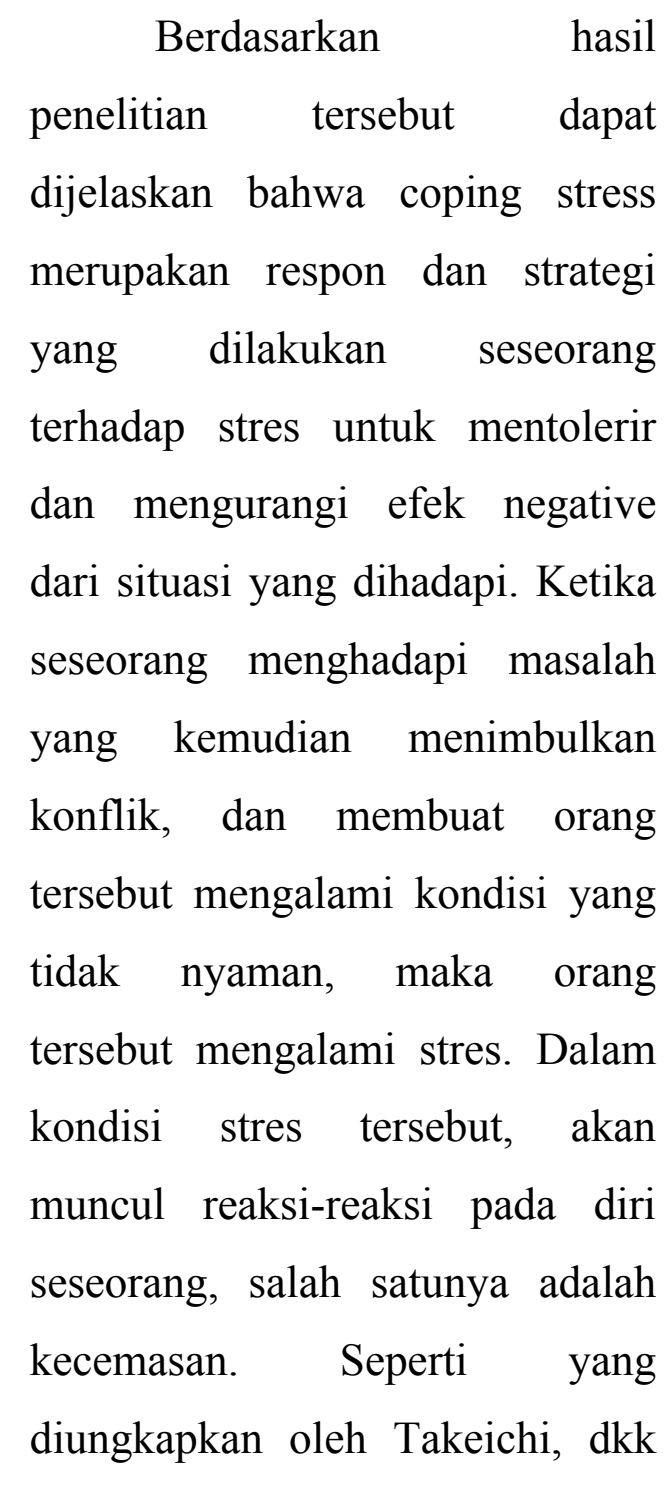

(2001, h.1) secara umum, ketika seseorang mengalami stres psikologis eksternal, individu akan memberikan makna subyektif terhadap stress yang dialami dan kecemasanpun terjadi.

Ketika orang mengalami kecemasan maka akan memicu munculnya usaha-usaha yang akan dilakukan guna mengatasi kecemasan yang dialami tersebut. Usaha-usaha atau teknik-teknik yang digunakan untuk mentolerir dan mengurangi stres dan kecemasan itulah yang disebut dengan coping stress. Coping stress merupakan respon dan strategi yang dilakukan individu terhadap stres untuk mentolerir dan mengurangi efek negative dari situasi yang dihadapi, termasuk didalamnya ketika orang mengalami kecemasan. Coping stress dapat dibagi menjadi dua, yaitu yang coping stress yang berorientasi pada peredaan emosi, dan coping stress yang 
berorientasi pada pemecahan masalah.

Kondisi tersebut di atas juga dapat dikenakan pada subjek penelitian. Ketika subjek penelitian adalah pelaku yang memiliki perilaku beresiko tinggi untuk terinveksi HIV/AIDS, dan ketika pelaku tersebut menjalani tes darah dan VCT, maka pelaku pun mengalami kondisi yang tidak enak atau tidak nyaman, yang dinamakan stres, serta reaksi dari stres tersebut bermacam-macam, salah satunya adalah kecemasan. Kecemasan yang dialami pelaku bermacam-macam, dapat berupa sindrom kecemasan, mulai episode singkat dari mood yang cemas, disertai gangguan penyesuaian diri, samapi pada gangguan cemas yang lebih berat, seperti gangguan panik atau gangguan stres akut (Hidayanti, 2013, h. 97). Saat para pelaku mengalami kecemasan, maka akan melakukan usaha-usaha yang dapat mentolerir atau mengurangi kecemasan yang dialaminya.
Usaha-usaha tersebut dinamakan coping stress. Ada yang melakukan usaha yang diarahkan untuk meredakan/menetralisir emosi (Emotion Focused Coping), ada juga yang melakukan usaha yang diarahkan untuk memecahkan masalah, artinya melakukan usaha-usaha untuk mengatasi masalah yang dialami (Problem Focused Coping), dalam hal ini terkait dengan terinveksinya HIV/AIDS.

Hubungan antara Emotion Focused Coping dengan kecemasan menunjukkan hasil koefisien korelasi yang negarif, dan sangat signifikan. Hal itu mengandung arti bahwa ketika subjek melakukan coping stress yang mengarah pada peredaan emosi , dapat menurunkan kecemasan yang dialaminya. Ketika seseorang memiliki masalah kemudian muncul situasi atau kondisi yang tidak nyaman, kemudian muncul reaksi kecemasan, maka pada awalnya reaksi emosi yang muncul akan 
coba diatasi dengan coping stress yang diarahkan untuk menetralisir emosi. Dalam subjek penelitian ditemukan beberapa kondisi bahwa ada beberapa subjek yang sedih, ada yang menyesal, ada yang pasrah, ada yang menerima kondisi yang terinveksi HIV/AIDS. Kondisi ini tidak bertahan lama, mereka segera mencari jalan pemecahan masalah yang dialaminya. Setelah emotion focused coping, mereka melakukan problem focused coping.

Menurut analisa data didapatkan hasil penelitian : ada hubungan negatif yang signifikan antara Problem Focused Coping dengan kecemasan. Itu berarti ketika subjek penelitian melakukan usaha-usaha yang diarahkan untuk memecahkan masalah, seperti melakukan konseling lanjutan, mencari dan melakukan pengobatan HIV/AIDS, atau tetap bekerja/berkarya meskipun sakit, akan mengurangi kecemasan yang dialami. Berdasarkan hasil wawancaradengan subyek, untuk mengurangi kecemasan mereka sehubungan dengan HIV/AIDS yang ia alami, hal yang dilakukan oleh mereka adalah:

1. Menceriterakan kondisinya kepada keluarga atau teman. Melalui keterbukaan kepada keluarga dan teman, beban subyek menjadi berkurang karena mereka memberikan semangat hidup.

2. Tetap bekerja di proyek konstruksi karena subyek merasa masih mampu bekerja seperti orang pada umumnya.

3. Aktif di dalam kegiatan kelompok yang diadakan oleh lembaga yang menaungi ODHA. Melalui kegiatan tersebut sesama anggota dapat saling sharing.

4. Menjadi pendamping bagi teman yang juga mengalami HIV/AIDS. Melalui program tersebut, ODHA diajak untuk terbuka dalam menceritakan pengalaman dan perasaan 
mereka serta melihat bahwa bukan hanya dia yang telah terinfeksi HIV/AIDS, sehingga ia tidak lagi merasa sendirian, kesepian, ataupun terkucilkan.

Uraian tersebut di atas semakin menguatkan hasil analisa data. Jadi baik emotion focuse coping maupun problem focused coping, mampu menurunkan kecemasan. Ketika seseorang kurang mampu melakukan coping, maka kecemasan akan semakin tinggi/meningkat.

Dalam penelitian ini salah satu bentuk coping dari emotion focused coping, yaitu escape avoidance (reaksi berkhayal dan usaha menghindar atau melarikan diri dari permasalahan), tidak mempunyai item yang valid. Hal ini disebakan subyek penelitian yang terlibat di dalam penelitian ini adalah mereka yang sudah berada di dalam lembaga yang peduli pada ODHA. Sehubungan dengan hal tersebut maka subyek akan memberi jawaban yang samauntuk item-item yang mengungkap escape avoidance karena sekarang mereka tidak sedang melarikan diri dari permasalahan.

\section{KESIMPULAN DAN SARAN}

Kesimpulan dari hasil penelitian ini adalah:

Ada hubungan yang negatif antara coping stres dengan kecemasan.

a. Ada hubungan yang negatif antara problem focused coping dengan kecemasan.

b. Ada hubungan yang negatif antara emotion focused coping dengan kecemasan.

Saran untuk orang yang yang terinfeksi HIV/AIDS dan peneliti selanjutnya:

a. Untuk mengurangi kecemasan, sebaiknya orang yang yang terinfeksi HIV/AIDS melakukan problem focused coping (melakukan usaha-usaha yang diarahkan untuk memecahkan masalah), seperti melakukan konseling lanjutan, mencari 
dan melakukan pengobatan HIV/AIDS, atau tetap bekerja/berkarya meskipun sakit, akan mengurangi kecemasan yang dialami. Emotion focused coping juga dapat mereka lakukan karena juga mampu mengurangi kecemasan. Misal: tidak begitu memikirkan masalah yang sedang dihadapi oleh subyek, berpikir bahwa ada hikmah dari semua masalah yang ada sekarang.

b. Untuk peneliti yang ingin mengembangkan hasil penelitian ini, sebaiknya melakukan penelitian secara kualitatif.

\section{DAFTAR PUSTAKA}

Carson, V. B. 2000. Mental Health Nursing. The nurse-patient journey. Philadephia: W. B. Saunders Company.

Finger, W. 2002. Youthlens on Reproductive Health and HIV/AIDS. USA
Folkman, S., Lazarus, R. S., Dunkel-Schetter, C., DeLongis, A., \& Gruen, R. 1986. The dynamics of a stressful encounter: Cognitive appraisal, coping and encounter outcomes. Journal of Personality and Social Psychology, 50, 992-1003.

Fauziah, F dan Widuri, J. 2005. Psikologi Abnormal Klinis Dewasa. Jakarta: UI Press Fayed, Husain, 2009, Kiat Menghadapi Rasa Was-was atau cemas, Solo: ABYAN. Meichati, S. 1983. Kesehatan Mental. Yogyakarta: Yayasan Penerbit Fakultas Psikologi UGM.

National AIDS Control Organization. 2004. Voluntary Counseling Testing. Goverment of India: Operational Guidelines.

Setyowati, D.Y. 2006. Coping Stress pada Mahasiswa Fakultas Psikologi 
Universitas Katolik

Soegijapranata Semarang yang Menempuh Mata

Kuliah Bimbingan Menulis

Skripsi Ditinjau dari Tipe

Kepribadian Ekstravert dan

Introvert. Skripsi. (tidak

diterbitkan). Semarang:

Fakultas Psikologi

Universitas Katolik

Soegijapranata.

Takeichi, M., Sato, T., Takefu, M., Shigematsu, M., Shimohira, H., Katsuki, T. 2001. Studies On The Psychosomatic Functioning Of III-Health Acording to
Eastern and Western

Medicine 5. Psychosomatic

Characteristic and Anxiety-

Affinitive Constitution.

American Journal of

Chinese Medicine. 